\title{
Body as Revolt: The Myth of Nangeli, the Woman who Covered her Breast
}

\section{OPEN ACCESS}

Manuscript ID:

ENG-2021-09044037

Volume: 9

Issue: 4

Month: September

Year: 2021

P-ISSN: 2320-2645

E-ISSN: 2582-3531

Received: 18.05.2021

Accepted: 16.07.2021

Published: 01.09.2021

Citation:

Ram, Kishore. "Body as

Revolt: The Myth of Nangeli, the Woman Who Covered

Her Breast." Shanlax

International Journal of

English, vol. 9, no. 4, 2021, pp. 1-8.

DOI:

https://doi.org/10.34293/

english.v9i4.4037

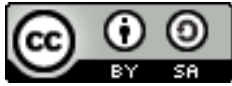

This work is licensed under a Creative Commons Attribution-ShareAlike 4.0 International License

\author{
Kishore Ram \\ Assistant Professor, Department of English, MMNSS College, Kottiyam, Kerala, India \\ (D) https://orcid.org/0000-0002-9910-2546
}

\section{Abstract}

The paper deals with the myth of Nangeli, a Dalit woman who stood against the improper tax structures that prevailed in the Kingdom of Travancore in Kerala. The paper also talks about the question of gender equality and the way women claim for equal opportunity with men by going topfree. The paper discusses the portrayal of the Nangelimyth in various art forms like paintings, fiction, film and graphic novels.

Keywords: Mulakkaram, Topfree, Caste system, Ayitham, Avarnar, Savarnar, Body protest

The Sun reports that in 2010 hundreds of women in New York protested by baring their breasts in open. "The mobilisation, known as Go Topless Day, encouraged protesters to unhinge their bras and free their nipples while proudly march through the streets in public." Women paraded the streets displaying cards and banners that carried slogans like: "war is obscene, not my nipples", "Free the nipple", "Your body is not a mistake" or "Let's make the body normal again". It marked the march which fell on 26 August 2010 as the Women's Equality Day and it happens to be the day when women earned their rights to vote based on Gender Equality in 1920.”(https://bit.ly/3txtzee)

As women around the world march top-bare as a gesture of protest claiming their rights to expose body, and celebrate freedom of liberating themselves, the condition of women a century ago in Kerala was not similar. In Travancore, in South Kerala, lower cast women could not cover their breasts and were compelled to pay a notorious tax called mulakkaramto cover their upper body. Women at that time protested against collecting tax based on the size of their breasts by covering it up. Women in ancient Kerala considered covering their breasts as a step towards liberation whereas their counterparts in modern world things baring breast is an act of liberation. In both cases body functions as tool of open rebellion against patriarchy.

Kerala is a state in South India and is proud of many achievements, including high literacy rate and well- managed public health system. It is a state that gives priority to women safety and care. The Kudumbashree project of the government ensures women empowerment and gives them pecuniary stability. However great the present day accomplishments are, it has a notorious past with lots of outrages against women of lower caste. Swami Vivekananda described Kerala as a madhouse when he saw the rigid caste system of the Nair dominated state.

The state pursued a caste system somewhat varied from the rest of India. The Brahmins were at the helm, the Kshathriyas and Nairs came next, and it marginalised the others as avarnars or lower caste. The merchant class did not exist in Kerala caste structure. 
RR Nair in "Kerala Society and Polity in the Second Half of the Nineteenth Century." (https:// bit.ly/3eueiqa) notes:

Caste is an endogamous group or a collection of endogamous groups. It bears a common name, and its membership is hereditary. Certain restrictions relating to social intercourse, occupations, etc. are imposed on every member. Unchangeable inequality based on birth and profession; and restrictions on marriage outside one's own group are indispensable principles of the caste system. Under the caste system, an individual's status is wholly predetermined. Men are born to their lot with no hope of changing it. So, a caste is a closed status group. It intensified the obligations and barriers to the utmost degree.

So uncompromising was the caste system in Kerala it was impossible for a person to escape from the caste hierarchy or to change his occupation or upward social mobility. The upper caste Hindus did all they could to keep the lower caste or avarnars away from the mainstream of activities. They had to keep a particular distance from an upper caste and had to walk away to mud or field on seeing a Brahmin approaching. Robin Jeffrey in The Decline of Nair Dominance notes:

A Nair may approach but not touch a Nambudiri Brahmin; a Chogan Irava must remain thirtysix places off, and a Poolayenninty-six steps distance. A Chogan must remain twelve steps away from a Nair, and a Poolayen sixty-steps off, and a Pariar some distance father still. A Syrian Christian may touch a Nair( though this is not allowed in some parts of the country) but the latter may not eat with each other. (9)

The ascribed status of the backward castes prevented people from getting educated and their upward mobility. Denial of education, right to worship and draw water from well were some ways in which the upper caste kept the caste structure intact.

Attires were another means managed by the upper caste for social control. The tropical warm and humid climate did not require more than one layer of clothes and this was discussed by the Seventeenth Century Dutch visitor William Van Nieuhoff. According to him the queen and many upper caste women went around with just a cloth covering their upper part partially. While visiting temples, Nair women used to remove their upper layer of clothes inside the temple. Before an upper caste the lower caste, both men and women, had to bare their chest and bow low. The Kshatriyas and Nair women could cover their breasts, but the lower caste could not wear a blouse or cover their breast.

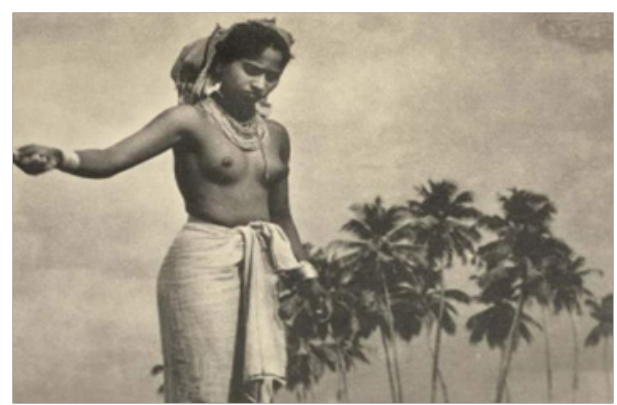

\section{Figure 1 An Avarna woman photo credit Sunil Janah | http://suniljanah.org}

Venkat Pulapaka observers,

Breast tax or locally known as Mulakkaram, which was prevalent in the Travancore Kingdom, was imposed on Dalit and backward class women. It was especially slapped on Avarna women, who belong to the lower caste. These women were forced to pay a tax on their breasts if they desired to cover their breasts with an upper cloth. In those days, women of low cast baring their breasts were showing respect to superior castes like the Namboodiris.( https://bit.ly/2SEkrrm)

Samuel Mateer in "Native Life in Travancore" says that the lower caste were burdened with the tax. Breast tax existed during the reign of Balarama Varma I (1798-1810), Queen Gowri Lakshmi Bayi (1810-1815) and Uthradom Thirunal Marthanda Varma II (1846-1860). Both men and women of the lower castes like the Ezhava and Nadar communities could not cover their chests before members of the upper caste. (Pulapaka).

Sonja Thomas observes that the upper castes like Brahmins, Kshathriya and Nairs wore white garments:

White garments became an embodiment of racial purity and set differences between - polluting $\|$ 
women. In comparison, low-caste women were not allowed the same grade of white cloth as Namboodiris, Nayars and Syrian Christians. Low-caste women including Ezhavas, Pulayas and Parayas traditionally wore the calla malla or stone necklace to denote subservience and eventually became a symbol of slavery.(83)

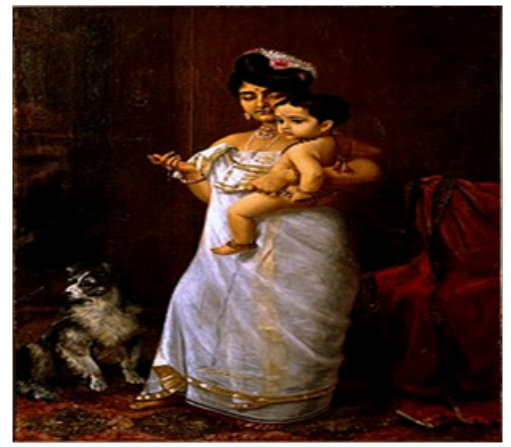

Figure 2: Ravi Varma depicts a Nair woma in the traditional mundumneryathum. (Source Wikpedia)

Conversion to Christianity helped overcome the shame of exposing breasts and it happened in places like Nagercoil and a huge number of Nadars despite the strong and violent attacks of Nairsconverted to Christianity and covered their upper body. The British also supported this move, but the upper caste prevented the lower caste from wearing the same attire as they wore and the women who got converted had to wear a distinct set of clothes to cover their upper part. It was called kuppayam.

It is curious to note that the upper caste women were not willing to allow lower caste women to wear clothes above their waist. The Queen herself was no exception. Edwin Sam S in his thesis entitled "Rev Charles mead and social reforms in south Travancore" points this out :

By an age-old custom, women of certain low castes had always been forbidden to wear an upper cloth or ornaments like those used by the high castes. The women who covered their bosom, contrary to the custom, were punished severely." The Rani of Attingal, ordered the breasts of a woman to be cut off, as she appeared in her presence with covered breasts. http://hdl. handle.net/10603/133914
As Christians got permission to cover their breast using 'Thol Cheelai' which was similar to those worn by upper castes, things went out of control. Public stripping of women, beating them up and burning huts occurred. Many Christian families had to escape to Nagercoil. The dominant Nair's were against Christianity as it prevented them from dominating the locals. Moreover, they got educated which led to a change of lifestyle. Edwin Sam $S$ notes:

Nearly half a century after introducing Protestant Christianity in South Travancore, the Christians came up remarkably in education and allied fields, and their lifestyle and standard of life improved a lot.", The annual report of the L.M.S. for the year 1850 says that in South Travancore there were seven congregational districts, nine Missionaries, 219 churches, 16889 Christians and 894 Catechists ( teachers of Christian religion).' over 5000 boys and girls had been in the schools run by the Missionaries. People bonded for hundreds of years, got liberation in June 1855 . http://hdl.handle.net/10603/133914

Eliza F. Kent Observes that conversion resulted in many advantages for the Christian converts deployed a wide variety of strategies to improve their social and economic conditions. They won many new advantages through their association with foreign missionaries, including right of access to public roads, exemption from extracted unpaid labour (uliayam), a regular day off from work to observe the Christian Sabbath.' (4) Kent notes that spaces that were inaccessible opened before them and it also led to change in women's role and right to education of the female child. The right to cover the upper body and a sense of modesty came into effect with conversion.

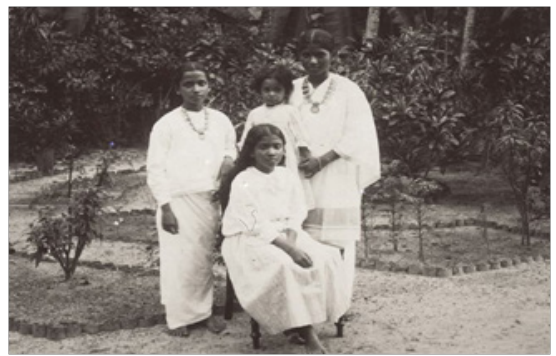

Figure 3 Syrian Christian women in Kerala https://bit.ly/3vfzSEU 
Though no historical evidences are available a myth that of Nangeli, an Ezhava woman, who resisted the mulakkaram is widely popular in Cherthala and Kollam. The myth goes like this: In Kerala, only upper caste woman belonging to the Brahmin community could cover their breasts in public. The women belonging to Kshatriya could cover their breasts but needed to expose themselves in front of Brahmin priests while visiting temples. They had to remove their upper clothes and tie it around the waist when they entered the temple premises. The same was the case with Nair women too. They had to remove their upper-clothes before Kshatriya's too. Thus the caste hierarchy worked with the upper casts. As the Vishay and Sudrasdid not exist in Kerala, the lower caste system or the avarnars were mainly Ezhava, Nadar, Pulayas, Kuravas .Clothes served the purpose of social control. The clothes of both men and women belonging to the lower caste were just a piece of cloth that could be tied around their waist and just reaching the knee. Thus the women belonging to the lower caste could never cover their breasts. However, a tax was introduced called mulakkaram and this allowed lower caste women to cover their breasts but a tax had to be paid for that. The tax was decided by the pravathiyar after examining the size of the woman's breast. Taxes differed according to the size.

In the article "Nangeli From Kerala: The Story Of The Woman Who Brought Casteism On Its Knees With Her Rebellion.” Homegrown Staff notes "The purpose of the breast-tax was to maintain the caste structure." Nangeli an Ezhava woman from Cherthala denied the pravathiyar, the tax-collector and village head the chance to collect breast tax. She defied the law and went around covering her breast. This was taken as an act of subversion and defiance to the social system by the upper caste, and they prompted the pravathiyar to collect tax from her. The pravathiyar was in for a shock for instead of tax Nangeli cut of her breast and offered it to him on a banana leaf. She died instantly and "her husband Chirukandan, according to Manu S Pillai in the Hindustan Times, 'he jumped into the pyre as Nangeli burned and perished in flames of grief - for him too there was sacrifice.' "
The revolt from the Nadar community of Thiruvananthapuram too added fuel to breast tax opposition and Sreemolam Thirunal, the then King of Travancore, issued a royal proclamation and took back the tax. Nangeli's protest was not just against the exposure of breast as it was common for even woman of upper caste to move around with their breast exposed or covered with just a shawl. Nangeli's protest was against the different tax lower caste people had to pay. Breast was just an excuse to collect tax from women for men it was called Thalakaram or the tax to cover head. Supriya Unni Nair in The News Minute notes that "breast tax was just one of the abhorrent measures in Kerala used to fill up the royal treasuries. Many strange and repressive taxes, such as "meniponnu" or cess on ornaments worn, and "meesha kazhcha" or cess to grow a moustache were levied, specifically on the backward and Dalit communities."

Unni highlights the freedom that women had. She says, "Being bare-chested was neither a mark of shame nor a forced show of respect, for men and women staying in the west coast of South India. They wore sparse lower body garments because of the weather conditions - such attire would aid evaporation of sweat, and prevent overheating in sultry humid climates. Hygiene and common sense dictated what they wore, not social norms." Hence it is to be noted that women in Kerala were not used to wearing any upper clothes and many upper caste women were portrayed with no upper clothes. Hence this was not a norm to just suppress the lower caste. Mulakkaramwas introduced to collect tax from people. Nangeli's protest was not just at being prevented by the right to cover her breast but also against the way the government levied taxes.

Nangeli's myth has gained wide popularity and it has been portrayed in various art forms like paintings, graphic stories, cinema, fiction and short film. OrijitSen has done a graphic sketch of the life of Nangeli in A Travancore Tale: The graphic story of Nangeli, the woman who cut off her breasts to protest a tax.

The graphic tale begins with an aged woman who begins the tale by saying "I believe my ancestor Nangeli knew what would happen if she continued to cover her breasts like the Nair women, and she 
was prepared." From this it is clear that the narrator is a descendent of Nangeli. It is a modern period from the backdrop. The woman narrates the tale of Nangeli by standing in front of a magnificent tiled house which looks like a palace or a tharavadu. An auto rickshaw and road can be seen signifying the present period. The next frame takes us back to the period when untouchability prevailed. A Nair woman is pictured sitting on a couch with her upper body covered, and the narrator tells how backward caste woman could not wear a blouse or cover their breasts like this Nair woman. The next picture talks about the mulakkaram and the injustice of having to pay the tax to cover the breast. The picture shows three women with their breasts exposed. Poverty surrounds them as they are seen engaged in work. In the next frame Nangeli appears with her breasts covered, while behind her a woman walks with it exposed. The picture also shows men gazing at her and an upper caste man saying she is headstrong. The story develops frame by frame, and the pravathiyar finally shows up demanding to examine her breast. The tax was to be paid in rice on a banana leaf. The picture showing a banana leaf and a sickle by its side prompts the reader to turn the page to view the next graphic image. Nangeli in the next frame stands with her upper cloth flung open allowing her breast to be closely examined by the pravathiyar and his men. The next five frames show the horror on the face of the pravathiyar as he witnesses Nangelichooping down her breast. The narrator sums up the tale by saying, "without waiting for his tax assessment, she made the payment." Right below this is a picture of the sickle falling on the ground and the banana leaf on which the breasts are offered are shown. The narrator then is seen standing on a balcony and points out the place where this incident occurred. She narrates how Nangeli's husband killed himself by jumping into her funeral pyre. The place is now called Mulachiparambu, or the land of the Breasted Woman.

The drawings are remarkably impressive and support to create awareness about the period mulakkaram existed. The poverty of the lower cast and their humiliation at having to move around exposing their breasts are well-depicted through the graphic images. The horror of cutting the breast is bought out brilliantly by illustrating the incident through the facial expression of the tax collector.

Yogesh Pagare's Breast Tax (2018) with Anushree Kushwaha as Nangelidraws the story of Nangeli myth in digital format. Cinematography by Jai Kamal Suthar and A.Sivamani's background score adds effect to the nineteenth century myth. The film was released in September 2018. The History genre short film is produced by Saummy Shivhare and Yogesh Pagare and released under the banner of Vijayshree Films. Mulakaram. The Breast Tax features Anushree Kushwaha, Saumyy Shivhare and Nazneen Patni in the lead roles.

The film opens with Nangeli and her friend colleting water from the river with two voyeuristic Brahmin youths staring hard at their breasts. This is rather uncommon and a wrong depiction as women in Travancore kingdom wore upper cloths only during cold season. Bare-breasted women were a common sight. MrinalPande twittered: "In Kerala, bare-breasted women were a common sight a century ago. My mother said they middle-class students tried gifting blouses to Adivasi girls who frequented the Shantiniketancampus, the girls turned it down saying they felt embarrassed to cover their torso!" (https:// bit.ly/3f7hjvK)

The Dutch representative William Van Nieuhoff describes Umayamma Rani, Queen of Kollam as:

"I was introduced into her majesty's presence. She had a guard of above 700 Nair soldiers about her, all clad after the Malabar fashion; the Queen's attire being no more than a piece of callicoewrapt around her middle, the upper part of her body appearing for the most part naked, with a piece of callicoe hanging carelessly round her shoulders. Her ears, which were long, her neck and arms were adorned with precious stones, gold rings and bracelets and her head covered with a piece of white callicoe. She was past her middle age, of a brown complexion, with black hair tied in a knot behind, but of majestickmein, she being a princess who shew'd a great deal of good conduct in the management of her affairs. "(https://bit.ly/3twLAJq)

Hence being bare breast was a choice among upper caste women and the lower caste could not cover theirs. The director's intention is to project 
the shame associated with being bare breast before men and to highlight why Nangeli went against such a tradition. The next shot shows both women leaving the premises quickly. Nangei is irked by the voyeuristic gaze of the upper caste men and her facial expression reveals it. In the next shot the two women are seen crouching down bare-breasted before their hut and engaged in baking bamboo baskets. This gives a good picture of the run-down conditions in which the outcasts had to stay for the upper castes had not permission to construct brick houses or to tile the roof.

Nangeli speaks out what is in her mind "Enough, I can't suffer this shame anymore." "They are raping us every day with their lustful eyes." The friends discuss their condition and compare it with the upper caste women who have every right to cover their breasts. Breast tax is discussed. The tax rates are so high that an ordinary family cannot pay it. "Why should the lower-caste woman pay tax according to the size and shape of her breast?" Nangeli asks. The aim of this tax according to Nangeli "is to keep the caste system intact" she feels that "religion, caste are only man-made and unjust." Nangeli's friend however feels that the lower-caste are born to suffer and the only option before them is to be quite and suffer more. Nangeli however is bound to change the law and to stop the suffering. She will go against the system.

Nangeli's husband Chirukandan steps forward to support her decision of covering her breast, but Nangeli reveals that her intention is not to pay the tax. It is not mere covering of the breast of concern for her, but she wants to change the social hierarchy and the weird tax system followed.

The next scene is a powerful one in which Nangeli wearing a cloth on her upper body is confronted by two Brahmins. They try to make her remove her cloth, but she uses the sickle to make them stay away from her. The scene has both Nangeli and her friend. While her friend walks bare breasted, she is covered.

In the next shot the pravathiyar comes to the house of Nangeli. He asks her to apologize for her mistake but she says that it is not a mistake but her right to cover her breast. The pravathiyar leaves with the warning he will be back after a month to collect the breast tax.
The scene in which Nangeli is confronted by the pravathiyar and his men to collect the breast tax forms the climax of the fourteen minute film. Nangeli is subjected to humiliation when made to stand exposing her breast as the pravathiyar assesses her breast and determines the tax she has to pay. But instead of the tax-rice measured out and handed to the pravathiyar on a banana leaf - she cuts off her breasts and hands it over. Seeing this horrific sight, the pravathiyar and his men run away. The film ends with Chirukandan jumping into the funeral pyre.

The short length of the film prevents the director to present many other issues that the poor had to suffer. The poverty of the people is not properly highlighted. The focus is only on the pleasure of gaze that men enjoy by seeing the half-naked women. But as sighted earlier the sight of bare upper body was common as both men and women did not cover it due to the warm humid weather. The director did not bring in a contrast by picturing a covered Nair or Brahmin woman. However, the film has pictured the might of a woman who took courage to stand against a patriarchal system that prevented a woman from covering her breast.

The myth also figures in literature: P.S. Menon has written a novel based on the theme and presents the story of Nangeli vividly. Quantum Theory, a short story by the author of this article, published in Journal of Literature and Aesthetics incorporates the myth by carefully webbing it into the main fabric of the story:

In Quantum Theory, Naryanan, a lower caste youth, is undergoing detention for sleeping in the classroom during a lecturer and along with him is a Nair girl undergoing the same punishment.

Narayanan glanced at his sleeping partner to see how she was progressing and as he spied at the pages of her notebook, his glance inadvertently fell on the bulge well concealed by the maroon blouse she wore. It was a distracting sight, and he suddenly felt his blood boiling inside his veins. He gripped his pen hard and focused on what he was writing ... Narayanan could not write any further; he kept his pen down and leaned forward to get a better view of what had attracted his eyes. He conjured up images of the peripherals well concealed by the maroon blouse. 
Narayanan's present act of voyeurism is justified by his rewriting history by gazing at a Nair woman's body parts, something that his ancestors had to undergo a century ago. He calls his grandmother saying.

'There was a time when the lower caste women were prohibited from covering their breasts. We had to pay Mulakkaram, a tax for covering breasts in public.'

Narayanan remembered the harrowing tales his grandmother had narrated to them.

It was an avarna woman, Nancheli, who put an end to this public shame. Nancheli cut both her breasts and presented it to the Pravarhtiar of the Travancore Stare as he rushed to her house to collect the breast-tax on hearing she was covering her bossom in public. Nanchelli eventually bled to death and her husband, Kandappan, sacrificed himself on her funeral pyre. The next day the breast tax was withdrawn.

His grandmother and his sisters must have undergone this public shame and must have been forced to reveal their breasts to the Namboodiris and Nairs as they scrutinized them critically. Now he was getting to avenge the social injustice women of his tribe had undergone. (128-129)

Narayanan is using the excuse of a century old practice to gaze at a woman's body part and gain voyeuristic pleasure. It is an act of revenge.

There existed many tribes all around the world where women went topfree. Both females and males went around without covering their upper body in many warm countries until Christian missionaries who found it unacceptable. The feeling of a sense of shame was slowly incorporated into the indigenous culture by the missionaries. With the spread of Islam covering the body became compulsory.

Movements like "Go Topless Day" aims to ascertain that men and women are equal. Just like a man, a woman has right to move around topfree. A movement called Topfreedom is gaining importance in many developed nations:

Top freedom is a cultural and political movement seeking changes in laws to allow women to be topless where men may be bare-chested, as a form of gender equality. Specifically, the movement seeks the repeal or overturning of laws which restrict a woman's right not to have her chest covered in public. (shorturl.at/cBGY2).

The sacrifice of Nangeli has not yet been recorded as a historic event. People in Cherthala believes this happened. When women around the world move for top freedom it is required to understand that a brave woman stood up to cover her breast and deny unlawful taxes to the government. Such bold acts should be incorporated in textbooks and recorded in the history of women's struggles for equality. In Kerala a century ago breast was not sexualised and the freedom enjoyed by women to expose their upper body existed. Covering of upper body was later used as a means of social control rather than as an act of modesty. Mulakkaram and Thalakkaram and such ridiculous taxes were introduced to fill the coffer of the local kingdoms. In a way Nanjeli's uses her body to revolt against the atrocities of the state and the upper caste.

\section{References}

Edwin Sam, S. Rev Charles Mead and Social Reforms in South Travancore. Manonmaniam Sundaranar University, 2005.

Kent, Eliza F. Converting Women: Gender and Protestant Christianity in Colonial South India. Oxford University Press, 2004.

Masters, Dave. "Women Strip for 'Go Topless Day'." The Sun, 2011.

Mateer, Samuel. Native Life in Travancore. Asian Educational Services, 1991.

Pulapaka, Venkat. "The History of Breast Tax and the Revolt of Lower Cast Women in 19th Century Travancore." STST World, 2019.

Nair, R.R. Kerala Society and Polity in the Second Half of the Nineteenth Century.

Nair, Supriya Unni. "Dress Code Repression: Kerala's History of Breast Tax for Avarna Women." The News Minute, 2016.

"Breast Tax - directed by Yogesh Pagare." IMDB, 2018.

Ram, Kishore. "Quantum Theory." Journal of Literature and Aesthetics, vol. 14, 2014, pp. 128-129.

Sen, Orijit. “A Travancore Tale: The Graphic Story of Nangeli, the Woman who cut off her 
Breasts to Protest a Tax." Scroll.in, 2017.

"Nangeli from Kerala: The Story of the Woman who Brought Casteism on its Knees with her Rebellion." HomeGrown, 2021.

Sonja, Thomas. From Chattas to Churidars: Syrian Christian Religious Minorities in a Secular
Indian State. State University of New Jersey, 2011.

"Then and Now." https://pazhayathu.blogspot. com $/ 2009 / 11 /$ kerala-women-toplesscostume-in-19th.html

\section{Author Details}

Dr. Kishore Ram, Assistant Professor, Department of English, MMNSS College, Kottiyam, Kerala, India

EmailID: kishkripa@gmail.com. 